Kadir Yildirim,

Sakarya University, Turkey

(iD) ORCID ID, 0000-0002-3122-9356

email: kadiry@sakarya.edu.tr

Metin Saygili,

Ph.D., Sakarya University of Applied Sciences, Turkey

(iD) ORCID ID, 0000-0001-6920-822X

email: msaygili@subu.edu.tr

Tolga Yalcintekin,

Ph.D., Turkey

(iD) ORCID ID, 0000-0001-7118-0705

email: tolgaylcntkn@gmail.com

Correspondence author: msaygili@subu.edu.tr

\title{
THE DETERMINANTS OF PURCHASE INTENTION AND WILLINGNESS TO PAY FOR COSMETICS AND PERSONAL CARE PRODUCTS
}

Abstract. This study focuses on purchase intention and willingness to pay based on consumer innovativeness, novelty seeking, and trustworthiness. In the study, the authors revealed the above in a holistic framework by emphasizing the direct relationships among the five variables. As this study focuses on consumers seeking novelty for cosmetics and personal care products in a constantly developing and growing sector, the study is different from the others and deemed necessary. This study seeks to examine the effect of consumer innovativeness, novelty seeking, and trustworthiness on purchase intention and willingness to pay for cosmetics and personal care products. It is quantitative research. The sample of the study consists of consumers aged 18 and over. The data of the study were collected from 407 people selected by convenience sampling via an online questionnaire. In the study, hypotheses were developed based on the conceptual framework and were tested via Structural Equation Modeling (SEM). The results of the study showed that consumer innovativeness had a positive effect on both purchase intention $(\beta=0.154 ; p<0.05)$ and willingness to pay $(\beta=0.317 ; p<0.05)$. While it was found that Novelty seeking had a positive effect on purchase intention $(\beta=0.312 ; p<0.05)$, it did not yield a statistically significant effect on willingness to pay $(\beta=0.018 ; p>0.05)$. The results also indicated that trustworthiness had a positive effect on both purchase intention $(\beta=0.427 ; p<0.05)$ and willingness to pay $(\beta=0.410 ; p<0.05)$. The structural equation model employed in the study explains $55 \%$ of the variance in consumers' purchase intention and $39 \%$ of the variance in willingness to share, respectively. The research results revealed that consumer innovativeness, novelty seeking, and trustworthiness are among the important determinants of purchase intention for cosmetics and personal care products and that consumer innovativeness and trustworthiness are influential on the formation of willingness to pay for these products.

Keywords: consumer innovativeness, cosmetics, personal care products, novelty seeking, purchase intention, trustworthiness, willingness to pay.

Introduction. Civilizations have always used cosmetics for beauty and health purposes in their religious rituals for centuries. Though, they are beyond compare to the current advanced cosmetics and personal care products. Dating back to 10,000 B.C. in Ancient Egypt, cosmetics are an integral part of Egyptian hygiene and health (Cosmetic Info, 2020). With the influence of popular culture on daily lives, cosmetics and personal care products have an important share among the products people buy and use intensively (Agcadağ, 2017). The 2017 data show that the consumption of cosmetics in the world amounts to 390 billion Euros based on retail price sales. While the largest markets are the EU and the USA, Turkey's share is around 0.7 (Cosmetics Europe, 2018; TOBB, 2018). A report published by the Republic of Turkey

Cite as: Yildirim, K., Saygili, M., \& Yalcintekin, T (2021). The Determinants of Purchase Intention and Willingness to Pay for Cosmetics and Personal Care Products. Marketing and Management of Innovations, 2, 11-24. http://doi.org/10.21272/mmi.2021.2-01 

Personal Care Products

Ministry of Trade (2021) indicates that the cosmetics and personal care products market is growing $10 \%$ on average per year in Turkey. The data of the present study were collected depending on the economic developments. It is estimated that the share of the products in the market is around $5 \%$. That is in line with the world market. An interesting detail in the report is that only $10 \%$ of the products marketed in Turkey are domestic. According to these data, personal care products, which have a significant share in the market, also play an important role in the purchasing behavior of consumers. Consumers make choices among brands before purchasing decision, that is in the evaluation stage. They might intend to purchase the most preferred brand based on their specific choices (Kotler and Keller, 2012). The purpose of the present study is to examine the role of consumer innovativeness, novelty seeking, and trustworthiness in the formation of willingness to pay and purchase intention for brands and products in the category of personal care products.

To gain the research purpose, this study consists of six sections, including the introduction. The second section of the study deals with the concepts of consumer innovativeness, novelty seeking, trustworthiness, purchase intention, and willingness to pay. In this section, some empirical models and hypotheses are given concerning the information obtained from the relevant literature review. The third section of the study covers methodology. This section offers information about sampling, measurement, and data collection. On the other hand, the fourth section involves data analysis and results. The fifth section shows the results of the hypothesis testing based on structural equation modeling. In addition, these two (fourth and fifth) sections present the findings and results obtained from the analyses carried out in this empirical study. The sixth section, which is the last one, is for conclusion and implications. While this section includes theoretical contributions and managerial implications, it also deals with the study's limitations and suggestions for future research.

Literature Review. In behavioral sciences, innovativeness is a rare concept directly related to consumer behavior (Hirschman, 1980). To Midgley and Dowling (1978), «innovativeness is the degree to which an individual is receptive to new ideas and makes innovation decisions independently of the communicated experience of others».

Consumer innovativeness is a potential personality trait that enables consumers to desire new and different experiences (Zhang and Hou, 2017). Rogers (1983) defined innovation as «an idea, practice, or object that is perceived as new by an individual or other unit of adoption». Based on this definition by Rogers, it is possible to argue that the extent of a consumer's innovativeness can be explained by his/her adoption of new ideas relatively earlier than others in his/her environment (Kotler and Keller, 2016). Uncertainty poses an important risk for consumers to adopt innovations early or late. To reduce this uncertainty, individuals should be informed in advance about all the advantages and disadvantages that may result from innovation (Sahin, 2006).

It stands to mention that many studies are discussing the relationship between consumer innovativeness and purchase intention in different contexts. In the study conducted by Yang (2010) within the context of the «Technology Acceptance Model» developed by Davis (1989), it was argued that innovativeness has an effect on behavioral intention and that the effect of innovativeness on behavioral intention to use mobile data services differs between the citizens of the two countries examined. The effect was argued to be stronger for Koreans than for Americans, which was supported by results. Shams et al. $(2017 ; 2020)$ argued that brand innovativeness positively affects purchase intention. Fu and Elliott (2013) dealt with innovativeness in a different category and examined the effect of product innovativeness on purchase intention. They showed that consumers' perceived product innovativeness has a positive relationship with purchase intention. San Martín and Herrero (2012) posited that a user's innovativeness in information technology positively affects online purchase intention, and their findings supported the hypothesis. Within the context addressed in this study, there are many studies in the literature suggesting that consumer innovativeness affects purchase intention (Al-Jundi et al., 2019; Nirmala and Dewi, 2011; 

Personal Care Products

Bülbül and Özoğlu, 2014).

In addition, there are studies (Zhang et al., 2020; Konuk, 2019) that examined the relationship between innovativeness and willingness to pay affecting consumer behavior such as purchase intention. Konuk's (2019) study on fair trade food indicated that consumer innovativeness positively affects both willingness to pay and willingness to buy. From this point of view, the following similar hypotheses are posited in this study:

H1: Consumer innovativeness has a positive effect on purchase intention.

H2: Consumer innovativeness has a positive effect on willingness to pay.

Being one of the concept developers having different conceptualizations about the nature of innovativeness and its connection with new product acceptance, Hirschman (1980) added novelty seeking and use innovativeness to behavioral innovativeness (Manning et al., 1995; Akdoğan and Kararslan, 2013), unlike Midgley and Dowling (1978). The basic idea leading to the emergence of novelty seeking is that the individual seeks new information through some intrinsic motivators or motivating powers and is mobilized to this end (Hirschman, 1980). Manning et al. (1995) narrowed down Hirschman's (1980) natural novelty definition: the desire to seek out new product information.

Rodriguez et al. (2017), concentrating on fruits of different sorts, investigated the effects of consumers' attitudes, subjective norms, and novelty seeking on purchase intention. The study revealed a significant effect of novelty seeking on purchase intention. Rachbini and Agustina (2019) determined that awareness of innovation positively affects attitude towards online social shopping and the search for ideas using eWOM via Facebook. They also reported that using eWOM to search for ideas positively affects purchase intention in purchases made via Facebook. Kim et al. (2020) posited that novelty seeking, in the context of omnichannel retailing, had a positive effect on repurchase intention and supported their argument with their findings. In addition, many studies show a relationship between consumer innovativeness and novelty seeking (Schweizer, 2006; Hirschman, 1980; Yagolkovskiy, 2019). Yagolkovskiy (2019) indicated a significant positive relationship between innovativeness and novelty seeking. Therefore, it is suggested that Novelty seeking also affects willingness to pay since consumer innovativeness positively affects willingness to pay (Zhang et al., 2020). Thus, the following hypotheses are posited in this study:

H3: Novelty seeking has a positive effect on purchase intention.

$\mathrm{H} 4$ : Novelty seeking has a positive effect on willingness to pay.

The ultimate goal of marketing is to create a strong bond between the consumer and the brand, and the most important factor in establishing this bond is trust. To Hiscock (2001), companies that succeed in establishing this bond would ensure customers' shopping from the company for many years. In addition, individuals with this bond play an important role in bringing those around them to the company. Trust is a concept that could be evaluated in an interpersonal or general context. In terms of interpersonal context, trust could be defined as believing in one's true and sincere intentions for the well-being and happiness of the other in the relationship between two people (Kiuru, 2014). In general terms, Moorman et al. (1992) define trust as «a willingness to rely on an exchange partner in whom one has confidence». By moving it beyond the interpersonal context, Sirdeshmukh et al. (2002) explain that trust is the consumer's confidence in the service provider and the expectation that they would fulfill their promises. Brand trust is an important component in successful marketing relations (Garbarino and Johnson, 1999). Chaudhuri and Holbrook (2001) define brand trust as «the willingness of the average consumer to rely on the ability of the brand to perform its stated function».

It is worth mentioning that many studies address the effect of trust on purchase intention in general (Lin and Lu, 2010; Watanabe et al., 2020; Kuşcu et al., 2019; Semuel and Chandra, 2014). In turn, Tong and Su (2018) studied young American consumers of organic clothing products. The researchers confirmed that consumer trust positively affects consumer purchase intention. Ali et al. (2018) concluded in their study on halal brands that halal brand trust significantly affects consumer's intention to purchase 

Personal Care Products

halal brands. Similar to the product group discussed in this study, Semuel and Chandra (2014) argued that trust affects consumers' purchase intention for a cosmetic product. Aydın et al. (2014) concluded in their study on baby care products of global and local brands that brand trust positively affects purchase intention. Liu et al. (2013) argued that website trustworthiness positively affects consumers' attitudes towards basket purchase. In other words, it was seen that trust affects purchasing behavior and attitude towards purchasing. Moreover, many studies reporting that trust affects willingness to pay (Aksoy and Özsönmez, 2019; Yıldız, 2018; Ghai and Sharma, 2019). Yıldız (2018) conducted a study on a shampoo brand, one of the personal care products, and argued that there is a significant relationship between brand trust and willingness to pay more. The results of that study showed that brand trustworthiness is a variable that directly affects willingness to pay. Therefore, the present study posits the following hypotheses.

$\mathrm{H} 5$ : Trustworthiness has a positive effect on purchase intention.

H6: Trustworthiness has a positive effect on willingness to pay.

Methodology and research methods. This study used a quantitative research technique based on a survey instrument for collecting data to test the hypothesized relationships empirically. In line with the purpose of the study, the main empirical data were obtained through convenience sampling by use of online surveys. They were gathered from consumers who were 18 years of age or older from different provinces of Turkey in May and July 2020. Before the respondents answered online questionnaires, they were informed of the research purpose. They were asked, as a pre-screening question, whether they had cosmetics and personal care products. After that, the respondents were requested to evaluate the cosmetics and personal care products they had and asked to answer the consumer innovativeness, novelty seeking, trustworthiness, purchase intention, and willingness to pay questions based on the relevant products. Within the scope of the main study, 435 surveys were administered to the consumers. The questionnaires returned by the respondents were checked for completeness, and 28 invalid surveys were removed. As a result, 407 valid surveys were kept for analysis. The demographic characteristics of consumers aged 18 and over who were users of cosmetics and personal care products are as follows. $58.9 \%$ are women, and $41.1 \%$ are men. $59.1 \%$ are single, and $40.9 \%$ are married. $36.3 \%$ have an undergraduate degree, $14.8 \%$ an associate degree, and $10.8 \%$ a graduate degree. $30.3 \%$ have a high school degree, and $7.8 \%$ have a primary school degree. $34 \%$ have a monthly income of $2,000 \mathrm{TL}$ or less, $16.3 \%$ a monthly income of 2,001 to $3,000 \mathrm{TL}, 13.3 \%$ a monthly income of 3,001 and $4,000 \mathrm{TL}, 12.3 \%$ a monthly income of $4,001-5,000 \mathrm{TL}$, and $24.1 \%$ a monthly income of $5,001 \mathrm{TL}$ or above. While $46.8 \%$ are in the $18-25$ age range, $24.3 \%$ in the $26-32$ age range, $18.7 \%$ in the $33-40$ age range, $7.4 \%$ in the $41-47$ age range, and $2.8 \% 48$ or over. A conceptual model was developed based on the abovementioned hypotheses (Figure 1). This model proposes that consumer innovativeness, novelty seeking, and trustworthiness influence purchase intention and willingness to pay for cosmetics and personal care products.

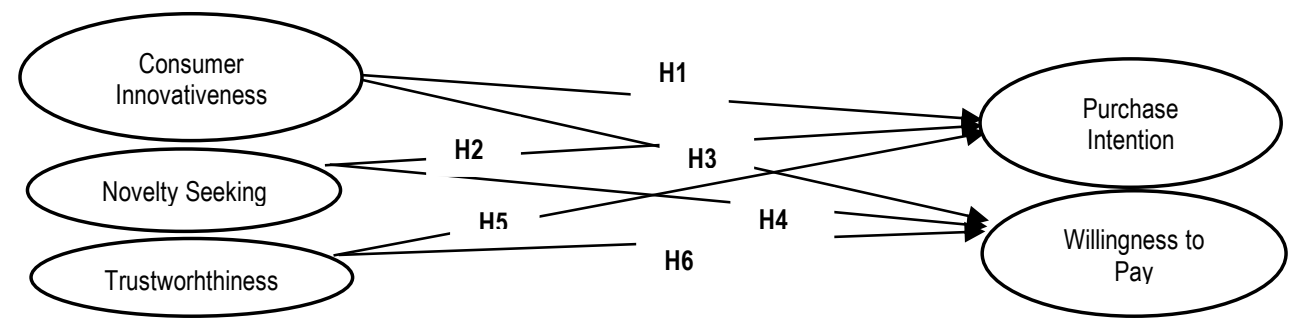

Figure 1. Research model

Sources: developed by the authors. 

Personal Care Products

The scales for measuring consumer innovativeness, novelty seeking, trustworthiness, purchase intention, and willingness to pay were adapted from previous studies. Joseph and Vyas (1984), Hur et al. (2012) adapted six items to measure consumer innovativeness, while Manning et al. (1995) - eight items to measure novelty seeking. Erdem and Swait (2004) adapted five items to measure trustworthiness. In turn, Konuk (2019) adapted three items to measure purchase intention and willingness to pay. All variables in the questionnaire were measured with a 5-point Likert-type scale ranging from strongly disagree to agree strongly. Initially, the «translation-back translation» strategy was employed to translate the scales used in the study. The experts in the field translated them from English to Turkish, then translated from Turkish back to English. Afterward, the text was compared with the original statements with the help of marketing academics. Various corrections were made to the statements in the scales based on that comparison. The aim was to ensure that the statements and concepts in the scales were understood correctly by the consumers in Turkey. Before the final study, three academicians and two experts were also interviewed to evaluate the scale's face validity (Davis et al., 2009; Edward et al., 2010). Then, a pilot study was performed on a group of 50 people to check the comprehensibility of the questionnaire questions and make the necessary adjustments and corrections in the form. Then the form was finalized based on the feedback obtained from the pilot study. The statements used for measuring the variables of consumer innovativeness, novelty seeking, trustworthiness, purchase intention, and willingness to pay, which are addressed within the scope of the study, are presented in the following section.

Results. 31-item and 5-factor covariance structure included in the model used in the study was examined in terms of the measurement model, structure validity, and reliability in the first place. Then the research hypotheses were tested with the structural model. To this end, the two-step approach suggested by Anderson and Gerbing (1988) was employed. The convergent validity and discriminant validity of the structures were analyzed to test the structure validity of the measurement model. Before structural model testing, the measurement model was evaluated in terms of fit indices, regression weights, and modification indices (MI). The fit indices obtained through CFA (confirmatory factor analysis) of the measurement model are $X^{2} / \mathrm{df}=3.364 ; \mathrm{GFI}=0.841 ; \mathrm{AGFI}=0.805 ; \mathrm{CFI}=0.915 ; \mathrm{NFI}=0.884 ; \mathrm{IFI}=0.915 ; \mathrm{TLI}=0.904 ; \mathrm{RMSEA}$ $=0.76$. The fit indices of the measurement model were not satisfactory. Therefore, the results indicated a need for improvement. In addition, the modification indices of the measurement model were examined. As it was seen that there was a relationship between some observed variables, covariance was assigned between the errors of those variables. Moreover, an analysis was made to see whether variables had high covariance with more than one variable among the variables whose modification indices were observed. Statements with high covariance in the table of modification indices were analyzed separately by including them in each covariance model. The modification was sustained, and as high relationships were seen between NS1 and NS3, included in the novelty seeking dimension, and TW4 and TW5, included in the trustworthiness dimension, covariance was assigned between the errors of those variables. As these modifications involve the links of the items within the same dimensions, they are logically understandable.

Following the statements removed from the analysis and the covariances included in the model, CFA was repeated. Based on the evaluation of the Ml of the model, Table 1 presents the statements removed from the analysis and the reasons for removing them.

Table 1. Statements removed as a result of first order CFA

\begin{tabular}{ccc}
\hline Structure & Item & Reason for Removal \\
\hline $\begin{array}{c}\text { Consumer } \\
\text { Innovativeness }\end{array}$ & $\begin{array}{c}\text { Before trying anything, I wait until it becomes popular on the market. } \\
\text { I am worried about trying new things. } \\
\text { I think too much money is spent on new things. }\end{array}$ & $\begin{array}{c}\text { Low standardized } \\
\text { regression coefficient }\end{array}$ \\
$\begin{array}{ccc}\text { Seeking } & \text { When I go shopping, I do not spend too much time checking for new } \\
\text { products and brands. } & \text { Low standardized } \\
\text { regression coefficient }\end{array}$ \\
\hline
\end{tabular}

Note: Any comments to the table

Sources: developed by the authors. 

Personal Care Products

The statements presented in Table 1 were removed from the analysis. Thus, the fit indices of the measurement model were re-evaluated. Table 2 shows the fit indices of the measurement model after the statements were removed from the analysis and the covariances were included in the model.

Table 2. Factor loadings and measurement model results

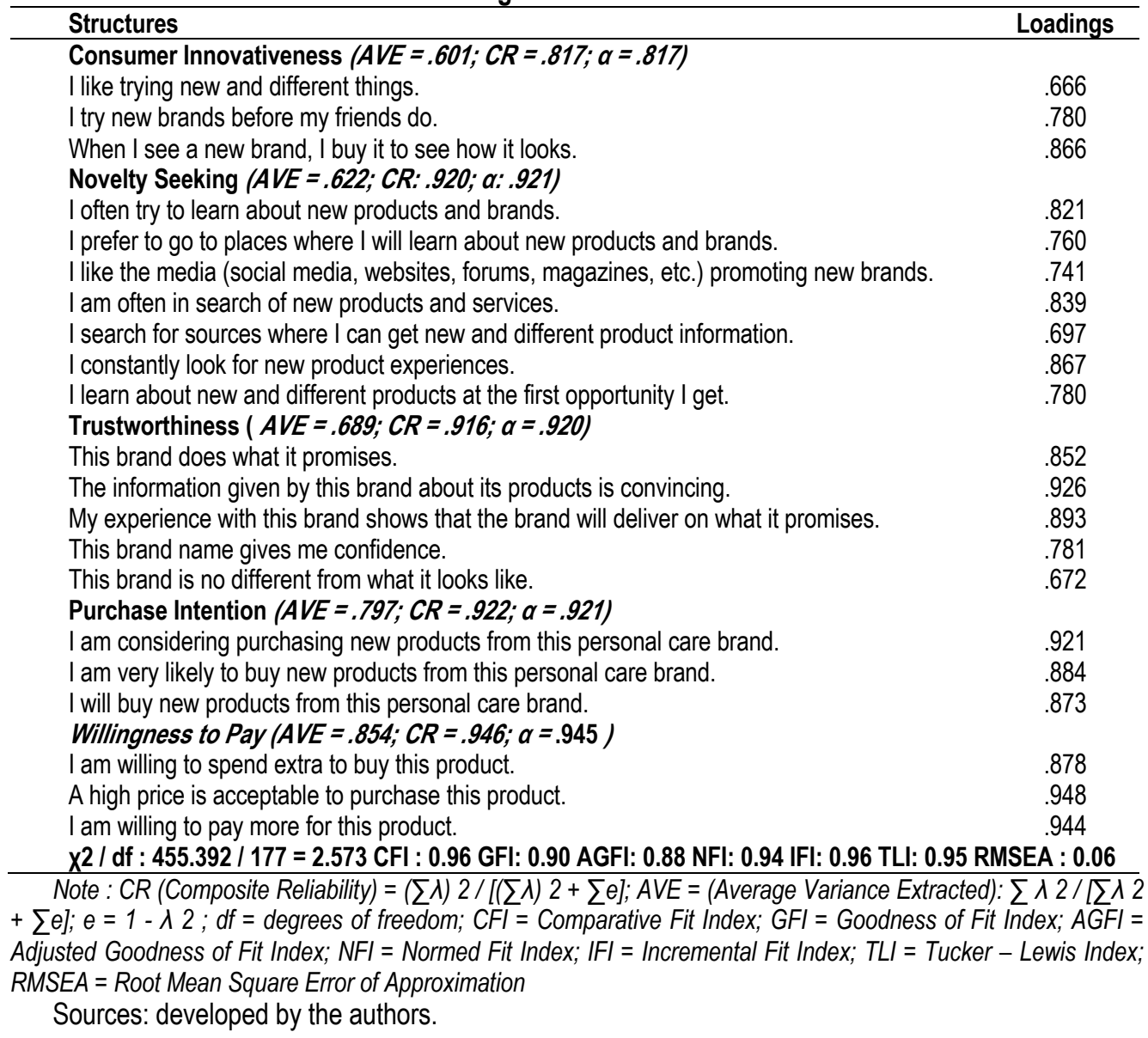

The fit indices of the measurement model in Table 2 are acceptable (Doll et al., 1994; SchermellehEngel et al., 2003; Mishra and Datta, 2011). These results show that the model is suitable for the data.

The structure validity of the scales was tested through convergent validity and discriminant validity. For checking convergent validity, the factor loading of each structure was evaluated. The standardized factor loading of each variable was found to be above 0.50 , proving convergent validity and the recommended value (Hair et al., 2010). In addition, since the average variance extracted (AVE) value for all structures was above the critical value of 0.50 , convergent validity was provided (Fornell and Larcker, 1981). The fact that AVE values are above the recommended value of 0.50 indicates that internal consistency is achieved (Berthon et al., 2005; Fornell and Larcker, 1981).

On the other hand, the relationship of each statement with the factor or structure to which it belongs was tested through CR and AVE to ensure convergent validity. Hair et al. (2010) emphasized that the AVE 

Personal Care Products

value should be greater than 0.5 (AVE> 0.5), and the $C R$ value should be greater than AVE (CR> AVE) for convergent validity. The analyses showed that the $C R$ values for each structure are greater than the AVE values and the AVE values are greater than 0.5 . Hence, it is possible to state that convergent validity is provided for the structures. The study used three different methods to evaluate discriminant validity: 1) Fornell-Larcker's (1981) criterion; 2) Bagozzi et al. (1991) method in which validity is tested using free and constrained models; 3 ) a new criteria assessment technique called HTMT (Heterotrait-Monotrait Ratio) proposed by Henseler et al. (2015). Table 3 shows the correlations of the structures and Cronbach's alpha, the CR, and the AVE values. Accordingly, the highest structure correlation is 0.785 , and it is below the suggested value of 0.85 . Therefore, it is possible to state that the measurement model provides discriminant validity (Kline, 1998). In addition, the square root of the AVE of each structure is greater than the correlations of each structure with the other structures in question, which is an indicator of discriminant validity (Fornell and Larcker, 1981). The values in Table 3 show that only the square root of the AVE value of consumer innovativeness structure is lower than its correlation with novelty seeking. This finding indicates that discriminant validity is provided for dimensions other than the consumer innovativeness structure.

Table 3. Correlations of the structures

\begin{tabular}{|c|c|c|c|c|c|c|c|c|}
\hline Structures & Cronbach $\alpha$ & CR & AVE & $\mathrm{Cl}$ & NS & TW & PI & WTP \\
\hline Consumer Innovativeness (Cl) &, 817 & 817 &, 601 &, $775^{*}$ & & & & \\
\hline Novelty Seeking (NS) & ,921 & ,920 & ,622 &, $785^{\star *}$ &, $789^{*}$ & & & \\
\hline Trustworthiness (TW) & ,920 & ,916 & 689 &, $401^{* *}$ &, $441^{* *}$ &, $830^{*}$ & & \\
\hline Purchase Intention (PI) & ,921 & ,922 & ,797 &, $550^{* *}$ &, $621^{* *}$ &, $614^{* *}$ &, $892^{*}$ & \\
\hline Willingness to Pay (WTP) & ,945 & ,946 & 854 &, $483^{* *}$ &, $437^{\star *}$ &, $532^{* *}$ & $654^{* *}$ &, $924^{*}$ \\
\hline
\end{tabular}

Discriminant validity was also tested using free and constrained models. For discriminant validity, the correlations between all dimensions were fixed to «1» and this «constrained model» was tested against an «unconstrained model» in which interdimensional correlations were set free (Bagozzi et al., 1991). The hypothesis for this test is $\mathrm{HO}: \Phi \mathrm{I}=1$. The $\Phi \mathrm{I} J$ shows the interdimensional correlation coefficients.

Table 4 shows $\times 2$ and $\mathrm{df}$ values for constrained and non-constrained models as well as their differences. If the $x 2$ difference $(\Delta x 2)$ between the two models is greater than the critical table value calculated for the difference of degrees of freedom ( $\Delta \mathrm{df}), \mathrm{H} 0$ is rejected. Thus, discriminant validity, which proves that each structure is separate, is provided.

Table 4. Discriminant validity results

\begin{tabular}{lcc}
\hline Models & $\mathrm{X}^{2}$ & Degrees of Freedom (df) \\
\hline Constrained model & 690,274 & 187 \\
Unconstrained model & 455,392 & 177 \\
$\Delta \mathrm{X}^{2}$ & 234,882 & \\
$\Delta \mathrm{df}$ & & 10 \\
\hline
\end{tabular}

Sources: developed by the authors.

As findings in Table 4 show that the $\Delta \times 2=234.882$ value is greater than the $10 \times 20.05=18.31$ table value, the $\mathrm{HO}$ hypothesis was rejected. Thus, discriminant validity was provided.

HTMT (Heterotrait-Monotrait Ratio) was also employed to provide discriminant validity between the 

Personal Care Products

structures (Henseler et al., 2015). Recently, Fornell and Larcker's (1981) approach is criticized by Henseler et al. (2015), who suggests a new criteria assessment technique called HTMT. This new approach is based on «the average of the correlations of indicators across structures measuring different phenomena relative to the average correlations of indicators within the same structure». HTMT ratio below 0.90 is acceptable for discriminant validity. For reaching sufficient validity, the ratio must be below 0.85 . Table 5 shows the result of the HTMT approach.

Table 5. The kesult of HTMT analysis

\begin{tabular}{cccccc}
\hline Structure & Cl & NS & TW & PI & WTP \\
\hline Cl & & & & & \\
NS & 0,766 & & & & \\
TW & 0,399 & 0,442 & & & \\
PI & 0,551 & 0,622 & 0,604 & 0,667 & - \\
WTP & $\mathbf{0 , 4 7 5}$ & $\mathbf{0 , 4 3 6}$ & $\mathbf{0 , 5 4 7}$ & \\
\hline
\end{tabular}

Sources: developed by the authors.

According to Table 5, all the values for each structure are lower than 0.85 . The obtained results showed that discriminant validity was provided for the structures. Cronbach's alpha and composite reliability (CR) statistics were employed to test the reliability of the scales. Table 3 shows the reliability values. The $a$ and $C R$ values for each of the structures are above the critical value of 0.70 (Hair et al., 2010), which indicates that all scales are reliable. Additionally, AVE values are above 0.50 (Berthon et al., 2005; Fornell and Larcker, 1981). Therefore, the findings show the internal consistency of the statements that measure each structure and indicate that the structures are reliable.

Test of Hypothesis.After the measurement model was supported in terms of structure validity and reliability, the hypotheses were tested via structural equation modeling. The standardized estimates of the model are shown in Figure 2. The goodness of fit statistics of the model are at an acceptable level $\left(X^{2} / \mathrm{df}\right.$ $=2.875, \mathrm{GFI}=0.89 ; \mathrm{AGFI}=0.86 ; \mathrm{CFI}=0.95 ; \mathrm{NFI}=0.93 ; \mathrm{IFI}=0.95 ; \mathrm{TLI}=0.94 ; \mathrm{RMSEA}=0.07$ ).

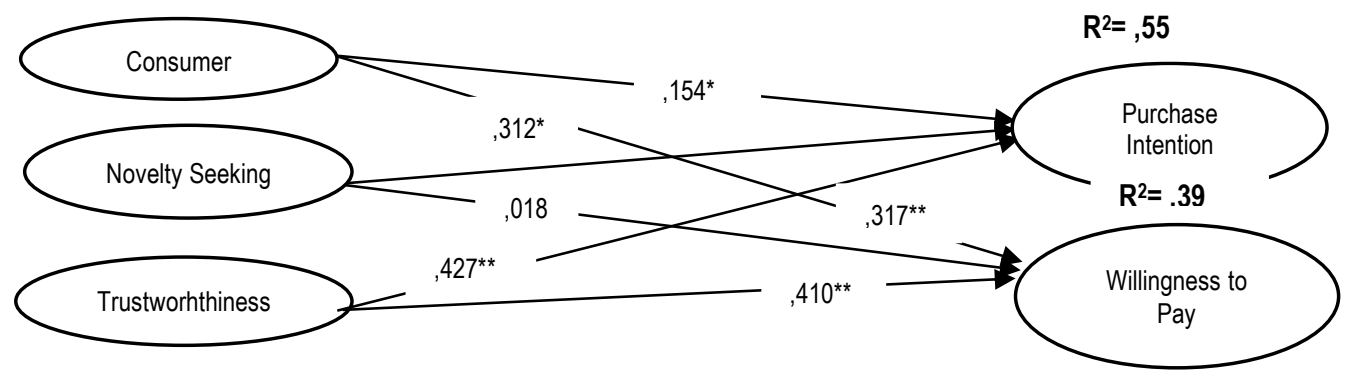

${ }^{*} p<0,05,{ }^{* *} p<0,001$

Figure 2. Parameter estimates of the structural model

Sources: developed by the authors.

The findings of the model revealed that consumer innovativeness has a positive effect on purchase intention ( $\beta=0.154 ; p<0.05)$ and willingness to pay $(\beta=0.317 ; \rho<0.001)$, accepting $H 1$ and $H 2$, respectively. As claimed in $\mathrm{H} 3$, a positive effect of novelty seeking on purchase intention is also confirmed $(\beta=0.312 ; p<0.001)$. The same observation did not come true in terms of the effect of novelty seeking on willingness to pay. Therefore, $\mathrm{H} 4$ was not confirmed $(\beta=0.018 ; p>0.05)$.

The empirical findings also suggest a positive effect of trustworthiness on both purchase intention and 

Personal Care Products

willingness to pay. Hence, $\mathrm{H} 5(=0.427 ; p<0.001)$ and $\mathrm{H6}(\beta=0.410 ; p<0.001)$ was confirmed. Moreover, the $\mathrm{R}^{2}$ value in Figure 2 shows that the structural equations model explained $55 \%$ of consumers' purchase intention variance and $39 \%$ of the willingness to pay.

Conclusion. The main purpose of this study is to understand the effect of consumer innovativeness, novelty seeking, and trustworthiness on purchase intention and willingness to pay high prices for personal care products. The conceptual framework of the research and the findings obtained through the study offer some theoretical contributions. This current empirical study contributes to the literature in the context of studies conducted in this field, with its premises and conclusions, focusing primarily on cosmetics and personal care products. In addition, this study makes an important contribution to the literature as it deals with the relationship between the consumers' novelty seeking, purchase intention, and willingness to pay more. This study deals with the effects of consumer innovativeness, novelty seeking, and trustworthiness on purchase intention and willingness to pay within the context of consumers' habits concerning cosmetics and personal care products. The results show that consumer innovativeness has a statistically significant positive effect on both purchase intention $(\beta=0.154 ; p<0.05)$ and willingness to pay $(\beta=0.317 ; p<0.001)$. These results reveal that the hypotheses $\mathrm{H} 1$ and $\mathrm{H} 2$ posited in the present study are confirmed. Previous studies conducted by Al-Jundi, Shuhaiber, and Augustine (2019), Nirmala and Dewi (2011), Bülbül and Özoğlu (2014), and Konuk (2019) report that consumer innovativeness affects purchase intention. In this sense, the results obtained in this study are similar to the findings of the studies mentioned above.

On the other hand, Zhang et al. (2020) and Konuk (2019) investigated the relationship between willingness to pay and consumer innovativeness. Konuk (2019) concluded that consumer innovativeness has a positive effect on willingness to pay. This result obtained by Konuk (2019) is consistent with the result obtained in the present study. The present study posited that novelty seeking has an effect on purchase intention in the $\mathrm{H} 3$ hypothesis. The obtained findings showed that novelty seeking has a statistically significant positive effect on purchase intention, and thereby confirming $\mathrm{H} 3(\beta=0.312 ; p$ $<0.001$ ). Rodriguez, Kulpavaropas, and Sar (2017) determine that novelty seeking has a significant effect on purchase intention. Rachbini and Agustina (2019) reveal that looking for ideas based on awareness of innovation positively affects purchase intention. In addition, the results of the study conducted by Kim, Costello, and Lee (2020) show that novelty seeking affects repurchase intention. The comparison of the results obtained in the present study with the results of these studies points to a similarity. On the other hand, $\mathrm{H} 4$ was formed to investigate the effect of consumers' novelty seeking on their willingness to pay. The results show that novelty seeking does not significantly affect willingness to pay $(\beta=0.018 ; p>0.05)$, thereby rejecting H4. There are studies (Schweizer, 2006; Hirschman, 1980; Yagolkovskiy, 2019) showing a relationship between consumer innovativeness and novelty seeking. According to Yagolkovskiy (2019), there is a significant positive correlation between innovativeness and novelty seeking. Therefore, it was posited that novelty seeking affects willingness to pay since consumer innovativeness positively affects willingness to pay (Zhang et al., 2020). The results obtained regarding the relationship in question differ from this argument. The results revealed that trustworthiness positively affects purchase intention ( $\beta=$ $0.427 ; p<0.001$ ), thereby confirming $\mathrm{H} 5$. Many studies in the literature generally address the effect of trustworthiness on purchase intention (Lin and Lu, 2010; Watanabe et al., 2020; Kuşcu, Durmaz, and Sazkaya, 2019; Semuel and Chandra, 2014). Tong and Su (2018) found that consumer trust has a positive effect on purchase intention. Ali et al. (2018) also concluded that brand trust significantly affects purchase intention. Similar to the results obtained in this study, Semuel and Chandra (2014) argued that trust affects consumers' purchase intention in the paper on a cosmetic product. Aydın et al. (2014) concluded that brand trust has a positive effect on purchase intention. That is to say, the results obtained in the studies in the literature are similar to the results obtained in the present study. Within the scope of $\mathrm{H6}$, which is the last hypothesis of the study, the effect of trustworthiness on willingness to pay was investigated. The result showed that $\mathrm{H} 6$ was confirmed. In other words, trustworthiness has a statistically significant positive 

Personal Care Products

effect on willingness to pay $(\beta=0.410 ; p<0.001)$. Previous studies in the literature showed that trustworthiness affects willingness to pay (Aksoy and Özsönmez, 2019; Yıldız, 2018; Ghai and Sharma, 2019). The results obtained in the present study are similar to the results of the abovementioned studies in the literature. In addition, the study conducted by Yıldız (2018) on a shampoo brand, one of the personal care products, reports that brand trust directly affects the desire to pay more. This result is consistent with the results of this study dealing with cosmetic and personal care products. The results obtained in this study show that innovativeness, novelty seeking, and trustworthiness affect consumer purchasing behavior. It is possible to reach some managerial implications from these findings.

In this sense, surveys on personal care products, which are innovative products in a highly competitive market, might affect consumers' recognition of these products and their purchase decision processes. Since the present study involves analyses on cosmetics and personal care products, the study results would help managers gain managerial information, including innovativeness, novelty seeking, consumer confidence in the brand, purchase intention, and consumers' willingness to pay for these products. For this reason, manufacturers of cosmetics and personal care products should have a reliable image and prepare innovative practices for consumers seeking novelty. Manufacturers producing such products should focus on being distinct from their competitors in terms of products and applications. Investments in organic personal care products, which are still a niche category in this field, and products with natural and innovative content may be a good opportunity to win health-conscious consumers. In addition, as in different product categories, consumer groups can be categorized as «baby care products, special care products developed for those with a special health problem, anti-aging products, and elderly care products». Considering the categorization of consumer groups, specialization and innovation studies in these product groups also play an important role in reaching the consumer groups as mentioned above. Moreover, businesses operating in this field could display an innovative brand image, making it easier to reach consumers looking for innovative products. In conclusion, the findings obtained in this study emphasize the importance of trustworthiness, novelty seeking, and innovativeness for creating purchase intention in consumers and for making them willing to pay higher prices for cosmetics and personal care products. Based on inferences to be made at this point, consumer commitment to businesses may be enhanced through innovative practices. Furthermore, it may be easier for businesses to adopt consumer innovativeness to reach consumers who have purchase intention and are willing to pay high prices.

Despite the theoretical contributions and managerial implications this study offers, it has some limitations. An important limitation of this study is the sampling method. Because the convenience sampling technique employed in this study is not a probability-based sampling technique, it is unknown whether it fully meets the characteristics of the universe. In this sense, the interpretation of the findings in the present study is limited to the sample of the study. The generalization of the research findings depends on further studies that will be done regarding cosmetics and personal care products and dwelling on the variables that constitute the focus of this study. Another limitation of this study is that it focuses on a single product category. Hence, only effects on consumers' cosmetics and personal care product preferences covered in the conceptual framework were analyzed in this study. The sample of this study includes only consumers who are 18 years old or older and who use cosmetics and personal care products in Turkey. In studies to be carried out based on consumer innovativeness, trustworthiness, and novelty seeking, it is important to dwell on samples with different consumer profiles to understand purchase intention and willingness to pay for cosmetics and personal care products. As stated in the Limitations section, the convenience sampling method employed to select the consumers constituting the sample of the present study does not allow generalization of the results. Although the relationships between variables were revealed by performing a structural model test, the study results are limited to this sample. For this reason, forming the sample group via the probability-based sampling method in future studies would contribute to the generalization of the results to be obtained. 

Personal Care Products

This study focused on a single product category. Thus, only effects on consumers' cosmetics and personal care product preferences covered in the conceptual framework were analyzed in this study. In future studies, effects covered in the conceptual model can be re-examined with a larger and different sample group and with studies to be conducted in another product category or without specifying a product category. Moreover, it is possible to compare the current results by focusing on different product categories in future research. In this study, no effect of novelty seeking was found on willingness to pay. It is an important finding for a product group like cosmetics and personal care products where consumers follow changes and innovations. It is essential to investigate in-depth why novelty seeking is not influential on willingness to pay for businesses in determining product and marketing strategies in future studies. In addition, we believe that the effect as mentioned above should also be scrutinized in various product groups such as technology and clothing. In this study, only consumer innovativeness, trustworthiness, and consumer novelty seeking were used to evaluate purchase intention and willingness to pay for cosmetics and personal care products. Future studies might add variables such as attitude and social impact to the ones covered in this study to investigate consumers' willingness to buy and pay. Furthermore, studies that would be carried out separately for each of the products such as shampoo, toothpaste, skin cream, and perfume, which are included in cosmetics and personal care products, based on socio-cultural variables, would help both researchers and marketing managers to reveal the situation regarding the willingness of consumers to purchase these products and pay high prices. Cosmetics and personal care products are among the sectors that are open to development and growth. Therefore, the revelation of consumer trustworthiness, purchase intention, and willingness to pay high prices could be an important determinant in structuring, especially the marketing mix elements for businesses since these products are frequently used in daily lives by adults. Besides, following innovative product policies is of great importance since the revelation of consumers' novelty seeking is a strategically important factor for product decisions. For this reason, researchers and academics might focus on providing findings that would light the way for businesses and practitioners that are to put much effort into innovative product research.

Author Contributions: prepared the outline of the paper, K. Y., T. Y. and M. S.; wrote abstract, T. Y. and K. Y.; developed theoretical background and literature review, K. Y. and M. S.; provided data and prepared methodology, M. S.; performed the analysis and visualization of results, T. Y. and M. S.; wrote discussion, K. Y. and T. Y.; was responsible for references control, M. S.

Funding: This research received no external funding.

\section{References}

Agcadağ, í. (2017). Popüler kültür bağlamında kozmetik ürünleri tüketimi ve yeni bir satış kanalı olarak ağ pazarlama (network marketing) sistemi. Sosyoloji Dergisi, 36, 157-169. [Google Scholar]

Akdoğan, M. Ş., \& Kararslan, M. H. (2013). Tüketici Yenilikciliği. Atatürk Üniversitesi İktisadi ve İdari Bilimler Dergisi, 27(2), 120. [Google Scholar]

Aksoy, H., \& Özsönmez, C. (2019). How Millennials' Knowledge, Trust, and Product Involvement Affect the Willingness to Pay a Premium Price for Fairtrade Products? Asian Journal of Business Research, 9(2), 95-112. [Google Scholar]

Ali, A., Xiaoling, G., Sherwani, M., \& Ali, A. (2018). Antecedents of consumers' Halal brand purchase intention: an integrated approach. Management Decision, 56(4), 715-735. [Google Scholar] [CrossRef]

Al-Jundi, S. A., Shuhaiber, A., \& Augustine, R. (2019). Effect of consumer innovativeness on new product purchase intentions through learning process and perceived value. Cogent Business \& Management, 6(1), 1-21. [Google Scholar] [CrossRef]

Anderson, J. C., \& Gerbing, D. W. (1988). Structural equation modeling in practice: A review and recommended two-step approach. Psychological bulletin, 103(3), 411-423. [Google Scholar]

Aydın, G., Ar, A. A., \& Taşkın, C. (2014). The role of brand trust on parents' purchase intentions of baby-care products. Doğuş Üniversitesi Dergisi, 15, 165-180. [Google Scholar]

Bagozzi, R. P., Yi, Y., \& Phillips, L. W. (1991). Assessing construct validity in organizational research. Administrative science quarterly, 36(3), 421-458. [Google Scholar] [CrossRef] 


\section{K., Yildirim, M., Saygili, T., Yalcintekin. The Determinants of Purchase Intention and Willingness to Pay for Cosmetics and}

Personal Care Products

Berthon, P., Ewing, M., \& Hah, L. L. (2005). Captivating company: dimensions of attractiveness in employer branding International journal of advertising, 24(2), 151-172. [Google Scholar] [CrossRef]

Bülbül, H., \& Özoğlu, B. (2014). Tüketici yenilikciliği ve algilanan riskin satin alma davranişina etkisi. Erciyes Üniversitesi İktisadi ve İari Bilimler Fakültesi Dergisi, 0(44), 43-58. [Google Scholar] [CrossRef]

Chaudhuri, A., \& Holbrook, M. B. (2001). The chain of effects from brand trust and brand affect to brand performance: the role of brand loyalty. Journal of marketing, 65(2), 81-93. [Google Scholar] [CrossRef]

Cosmetic Info. (2020). A History of Cosmetics from Ancient Times. Retrieved from [Link]

Cosmetics Europe. (2018). Socio-Economic Contribution of the European Cosmetics Industry Report. Rertrieved from [Link]

Davis, D. F., Golicic, S. L., \& Marquardt, A. (2009). Measuring brand equity for logistics services. The International Journal of Logistics Management. 20(2), 201-212. [Google Scholar] [CrossRef]

Davis, F. D. (1989). Perceived usefulness, perceived ease of use, and user acceptance of information technology. MIS quarterly, 13(3), 319-340. [Google Scholar] [CrossRef]

Doll, W. J., Xia, W., \& Torkzadeh, G. (1994). A Confirmatory factor analysis of the end-user computing satisfaction instrument. MIS Quarterly, 18(4), 453-461. [Google Scholar] [CrossRef]

Edward, M., George, B. P., \& Sarkar, S. K. (2010). The Impact of switching costs upon the service quality-perceived valuecustomer satisfaction service loyalty chain: A study in the context of cellular services in India. Services Marketing Quarterly, 31 (2), 151-173. [Google Scholar] [CrossRef]

Erdem, T., \& Swait, J. (2004). Brand credibility, brand consideration, and choice. Journal of consumer research, 31(1), 191198. [Google Scholar] [CrossRef]

Fornell, C., \& Larcker, D. F. (1981). Evaluating structural equation models with unobservable variables and measurement error. Journal of marketing research, 18(1), 39-50. [Google Scholar] [CrossRef]

Fu, F. Q., \& Elliott, M. T. (2013). The moderating effect of perceived product innovativeness and product knowledge on new product adoption: An integrated model. Journal of Marketing Theory and Practice, 21(3), 257-272. [Google Scholar] [CrossRef]

Garbarino, E., \& Johnson, M. S. (1999). The different roles of satisfaction, trust, and commitment in customer relationships. Journal of marketing, 63(2), 70-87. [Google Scholar] [CrossRef]

Ghai, S., \& Sharma, A. (2019). Effect of Perceived Health Benefits and Trust on Customer's Satisfaction \& Willingness to Pay for Organic Foods. Indian Journal of Community Health, 31(1), 123-126. [Google Scholar]

Hair, J. F., Black, W. C., Babin, B. J., \& Anderson, R. E. (2010). Multivariate data analysis. New Jersey. Pearson Prentice Hall: Upper Saddle River. [Google Scholar]

Henseler, J., Ringle, C. M., \& Sarstedt, M. (2015). A new criterion for assessing discriminant validity in variance-based structural equation modeling. Journal of the academy of marketing science, 43(1), 115-135. [Google Scholar] [CrossRef]

Hirschman, E. C. (1980). Innovativeness, novelty seeking, and consumer creativity. Journal of consumer research, 7(3), 283-

295. [Google Scholar] [CrossRef]

Hiscock, J., (2001). Most Trusted Brands, Marketing, March 1st, 32-33. [Link]

Hur, W. M., Yoo, J. J., \& Chung, T. L. (2012). The consumption values and consumer innovativeness on convergence products.

Industrial Management \& Data Systems. 112( 5), 688-706. [Google Scholar] [CrossRef]

Joseph, B., \& Vyas, S. J. (1984). Concurrent validity of a measure of innovative cognitive style. Journal of the Academy of Marketing Science, 12(1-2), 159-175. [Google Scholar] [CrossRef]

Kim, C., Costello, F. J., \& Lee, K. C. (2020). The Unobserved Heterogeneneous Influence of Gamification and Novelty seeking Traits on Consumers' Repurchase Intention in the Omnichannel Retailing. Frontiers in Psychology, 11:1664, 1-21. [Google Scholar] [CrossRef]

Kiuru, K. (2014), The relationship between brand love and positive word of mouth. Unpublished Master's Thesis, Jyväskylä School Of Busıness And Economıcs, Jyväskylä, Finland. [Google Scholar]

Kline, R. B. (1998). Principles And Practice Of Structural Equation Modeling. NJ: The Gilford Press. [Google Scholar]

Konuk, F. A. (2019). Consumers' willingness to buy and willingness to pay for fair trade food: The influence of consciousness for fair consumption, environmental concern, trust and innovativeness. Food Research International, 120, 141-147. [Google Scholar] [CrossRef]

Kotler, P. \& Keller, K.L. (2012). Marketing Management. 14th Edition, Pearson Education. [Google Scholar]

Kotler, P. \& Keller, K.L. (2016). A Framework for Marketing Management. 6th Edition, Pearson Education. [Google Scholar]

Kuşcu, A. T., Durmaz, B. V., \& Sazkaya, M. K. (2019). Algılanan Kurumsal Sosyal Sorumluluğun Satın Alma Niyeti Üzerindek Etkisinde Güvenin Araclık Rolü. Celal Bayar University Journal of Social Sciences/Celal Bayar Üniversitesi Sosyal Bilimler Dergisi, 17(4), 160-172. [Google Scholar] [CrossRef]

Lin, L. Y., \& Lu, C. Y. (2010). The influence of corporate image, relationship marketing, and trust on purchase intention: the moderating effects of word-of-mouth. Tourism review, 65(3), 16-34. [Google Scholar] [CrossRef]

Liu, M. T., Brock, J. L., Shi, G. C., Chu, R., \& Tseng, T. H. (2013). Perceived benefits, perceived risk, and trust: Influences on consumers' group buying behaviour. Asia Pacific Journal of Marketing and Logistics, 25(2), 225-248. [Google Scholar] [CrossRef]

Manning, K. C., Bearden, W. O., \& Madden, T. J. (1995). Consumer innovativeness and the adoption process. Journal of consumer psychology, 4(4), 329-345. [Google Scholar] [CrossRef] 
Midgley, D. F., \& Dowling, G. R. (1978). Innovativeness: The concept and its measurement. Journal of consumer research, 4(4), 229-242. [Google Scholar] [CrossRef]

Mishra, P., \& Datta, B. (2011). Perpetual asset management of customer-based brand equity-The PAM evaluator. Current Research Journal of Social Sciences, 3(1), 34-43. [Google Scholar]

Moorman, C., Zaltman, G., \& Deshpande, R. (1992). Relationships between providers and users of market research: The dynamics of trust within and between organizations. Journal of marketing research, 29(3), 314-328. [Google Scholar] [CrossRef]

Nirmala, R. P., \& Dewi, I. J. (2011). The effects of shopping orientations, consumer innovativeness, purchase experience, and gender on intention to shop for fashion products online. Gadjah mada international journal of business, 13(1), 65-83. [Google Scholar]

Rachbini, W., \& Agustina, A. (2019). Customer style inventory, the usage of Facebook, and purchase intention: are they connected?. Jurnal Siasat Bisnis, 23(1), 67-81. [Google Scholar] [CrossRef]

Rodriguez, L., Kulpavaropas, S., \& Sar, S. (2017). Testing an Extended Reasoned Action Framework to Predict Intention to Purchase Fruits With Novel Shapes. Journal of Agricultural \& Food Information, 18(2), 161-180. [Google Scholar] [CrossRef] Rogers, E. M. (1983). Diffusion of Innovations. Third Edition, Newyork: Simon and Schuster. [Google Scholar]

Sahin, I. (2006). Detailed review of Rogers' diffusion of innovations theory and educational technology-related studies based on Rogers' theory. Turkish Online Journal of Educational Technology-TOJET, 5(2), 14-23. [Google Scholar]

San Martín, H., \& Herrero, Á. (2012). Influence of the user's psychological factors on the online purchase intention in rural tourism: Integrating innovativeness to the UTAUT framework. Tourism Management, 33(2), 341-350. [Google Scholar] [CrossRef]

Schermelleh-Engel, K., Moosbrugger, H., \& Müller, H. (2003). Evaluating the fit of structural equation models: Tests of significance and descriptive goodness-of-fit measures. Methods of psychological research online, 8(2), 23-74. [Google Scholar]

Schweizer, T. S. (2006). The psychology of novelty-seeking, creativity and innovation: neurocognitive aspects within a workpsychological perspective. Creativity and Innovation Management, 15(2), 164-172. [Google Scholar] [CrossRef]

Semuel, H., \& Chandra, S. S. (2014). The analysis of corporate social responsibility implementation effects towards price fairness, trust and purchase intention at Oriflame cosmetics product in Surabaya. Procedia-Social and Behavioral Sciences, 155, 42-47. [Google Scholar] [CrossRef]

Shams, R., Brown, M., \& Alpert, F. (2017). The role of brand credibility in the relationship between brand innovativeness and purchase intention. Journal of Customer Behaviour, 16(2), 145-159. [Google Scholar] [CrossRef]

Shams, R., Brown, M., \& Alpert, F. (2020). A model and empirical test of evolving consumer perceived brand innovativeness and its two-way relationship with consumer perceived product innovativeness. Australasian Marketing Journal (AMJ), 28(4), 171180. [Google Scholar] [CrossRef]

Sirdeshmukh, D., Singh, J., \& Sabol, B. (2002). Consumer trust, value, and loyalty in relational exchanges. Journal of marketing, 66(1), 15-37. [Google Scholar] [CrossRef]

TOBB (Türkiye Odalar ve Borsalar Birliği). (2018). Türkiye Kozmetik ve Temizlik Ürünleri Sanayi Raporu 2017. Retrieved from [Link]

Tong, X., \& Su, J. (2018). Exploring young consumers' trust and purchase intention of organic cotton apparel. Journal of Consumer Marketing, 35(5), 522-532. [Google Scholar] [CrossRef]

Türkiye Cumhuriyeti Ticaret Bakanlığı (Republic of Turkey Ministry of Trade). (2021). Kozmetik Sektörü, Sektör Raporları. Retrieved from [Link]

Watanabe, E. A. D. M., Alfinito, S., Curvelo, I. C. G., \& Hamza, K. M. (2020). Perceived value, trust and purchase intention of organic food: a study with Brazilian consumers. British Food Journal, 122(4), 1070-1184. [Google Scholar] [CrossRef]

Yagolkovskiy, S. (2019). Relationships among individual-level correlates of innovation. International Journal of Innovation Science, 11(2), 196-207. [Google Scholar] [CrossRef]

Yang, K. (2010). The effects of technology self-efficacy and innovativeness on consumer mobile data service adoption between American and Korean consumers. Journal of International Consumer Marketing, 22(2), 117-127. [Google Scholar] [CrossRef]

YIldı, E. (2018). Sosyal Pazarlama Uygulamaları ve Marka Iletişiminin Marka Güveni ve Daha Fazla Ödeme İsteği Üzerindeki Etkileri: Head \& Shoulders Markası Üzerine Bir Araştırma. İşletme Araştırmaları Dergisi, 10(3), 471-487. [Google Scholar]

Zhang, F., Sun, S., Liu, C., \& Chang, V. (2020). Consumer innovativeness, product innovation and smart toys. Electronic Commerce Research and Applications, 41, 1-13. [Google Scholar] [CrossRef]

Zhang, Z., \& Hou, Y. (2017). The effect of perceived risk on information search for innovative products and services: the moderating role of innate consumer innovativeness. Journal of Consumer Marketing, 34(3), 241-254. [Google Scholar] [CrossRef]

Кадір Їлдирим, Університет Сакарії, Туреччина

Метін Сайгилі, Ph.D., Університет прикладних наук Сакарії, Туреччина

Толга Ялчинтекін, Ph.D., Туреччина

Детермінанти поведінки споживачів на ринку косметичних товарів та засобів особистої гігієни

У статті проаналізовано взаємозв'язок між рівнями інноваційнойсті споживачів, їх інтенсивністю пошуку нових товарів, надійності, мотивами та готовністю сплачувати за товари косметичної індустрії та засоби особистої гігієни. Емпіричне дослідження проведено на основі панельних даних, сформованих на результатах опитування 407 респондентів віком старше 18 років. Для перевірки висунутих гіпотез застосовано структурне моделювання (Structural Equation Modeling). 

Personal Care Products

Отримані результати засвідчили статистично значущий позитивний вплив рівня інноваційності споживачів на їх мотиви та готовність сплачувати за товари косметичної індустрії $(\beta=0,154 ; p<0,05)$ та засоби особистої гігієни $(\beta=0,317 ; p<0,05)$. Встановлено, що пошук нових товарів має статистично знначущий позитивний вплив на мотиви споживачів купувати товари косметичної індустрії та засоби особистої гігієни $(\beta=0,312 ; p<0,05)$. Однак, авторами емпірично обгрунтовано відсутність статистично значущого впливу пошуку нових товарів споживачами на їх готовність платити за товари косметичної індустрії та засоби особистої гігієни $(\beta=0,018 ; p>0,05)$. За результатами тестування гіпоттез визначено статистично значущий позитивний вплив рівня надійності споживачів на на мотиви споживачів та їх готовність сплачувати за товари косметичної індустрії $(\beta=0,427 ; p<0,05)$ та засоби особистої гігієни $(\beta=0,410 ; p<0,05)$. Структурне можелювання пояснює $55 \%$ відхилення у намірах спожвачів здійснити купівлю та $39 \%$ відхилення у бажанні ділитися товарами косметичної індустрії та засобами особистої гігієни. Враховуючі емпіричні результатами дослідження авторами наголошено, що рівень інноваційності споживчів, їх інтисивність пошуку нових товарів та рівень надійності споживачів $є$ статистично значущими факторами, які впливають на мотиви споживачів купувати товари косметичної індустрії та засоби особистої гігієни. При цьому рівні інноваційності та надійності сприяють готовності платити за ці продукти.

Ключові слова: споживча інноваційність, косметика, засоби особистої гігієни, пошук новинок, купівельні наміри, авторитетність, готовність платити. 